\title{
Quality of mechanical peanut sowing and digging using autopilot
}

\author{
Cristiano Zerbato ${ }^{1}$, Carlos E. A. Furlani ${ }^{1}$, Mailson F. de Oliveira ${ }^{1}$, Murilo A. Voltarelli ${ }^{2}$, \\ Tiago de O. Tavares ${ }^{1} \&$ Franciele M. Carneiro ${ }^{1}$
} ${ }^{1}$ Universidade Estadual Paulista/Faculdade de Ciências Agrárias e Veterinárias/Departamento de Engenharia Rural. Jaboticabal, SP, Brasil. E-mail:
cristiano.zerbato@unesp.br - ORCID: 0000-0002-4534-5454; eduardo.furlani@unesp.br - ORCID: 0000-0002-1508-5372; mailson.oliveira@unesp.br
(Corresponding author) - ORCID: 0000-0003-4771-0424; tiagoolitavares@hotmail.com - ORCID: 0000-0003-3040-5482; franmorlin1@gmail.com -
ORCID: 0000-0003-0117-7468
${ }^{2}$ Universidade Federal de São Carlos/Centro de Ciências da Natureza/Campus Lagoa do Sino. Buri, SP, Brasil. E-mail: voltarelli.ufscar@gmail.com -
ORCID: 0000-0002-3774-1705

\begin{abstract}
Over the past decade, automatic guidance of agricultural machinery via Global Navigation Satellite System (GNSS) signals has been increasingly adopted by the farming community. Peanut farmers are adopting such technology in order to improve the parallelism of operations to address difficulties that occur in mechanical digging, where losses are a big problem. This study aimed to evaluate mechanized operations of peanut sowing and digging controlled manually and by autopilot, along with their quality. The treatments consisted of two digging operations, with and without autopilot, and two displacement speeds $\left(4.5\right.$ and $\left.6.0 \mathrm{~km} \mathrm{~h}^{-1}\right)$. The experiment was conducted in a mediumtextured soil in a completely randomized design arranged in bands, using the analyzed variables as quality indicators. At sowing, parallelism between passes of the tractor-sower set, was evaluated at 120 points of each system (manual and automatic routing). The digging losses were evaluated in the two guidance systems, under two displacement speeds (4.5 to $6.0 \mathrm{~km} \mathrm{~h}^{-1}$ ) at 15 points per treatment. It was verified that the parallelism between the passes of the tractor-sower set was better when using the autopilot, which improved the operation quality. Displacement speed did not influence the digging loss. There were no differences in the visible digging loss, but higher quality was obtained when the operation was performed using autopilot. Minor invisible and total digging losses were obtained when the digging was performed with automatic routing, and superior quality was found at a speed of $4.5 \mathrm{~km} \mathrm{~h}^{-1}$; however, quality was adversely affected under manual operation. Thus, the use of autopilot is effective for improving the accuracy and the quality of the operations.
\end{abstract}

Key words: Arachis hypogaea L., statistical process control, kinematic relative positioning, parallelism, digging losses

\section{Qualidade da semeadura e do arranquio mecanizados de amendoim com uso do piloto automático}

RESUMO: O direcionamento automático de máquinas agrícolas via sinal GNSS (Global Navigation Satellite System) tem sido adotado cada vez mais pela comunidade agrícola na última década. Produtores de amendoim estão adotando tal tecnologia a fim de melhorar o paralelismo das operações face às dificuldades principalmente encontradas no arranquio mecanizado, onde as perdas são, todavia, um grande problema. Objetivou-se avaliar as operações mecanizadas de semeadura e de arranquio de amendoim controlados manualmente e com piloto automático, juntamente com a qualidade das operações. Os tratamentos consistiram de duas operações de escavação, com e sem piloto automático, e duas velocidades de deslocamento $\left(4,5 \mathrm{e} 6,0 \mathrm{~km} \mathrm{~h}^{-1}\right)$. O experimento foi realizado em solo de textura média, sob delineamento inteiramente casualizado disposto em faixas, utilizando-se das variáveis analisadas como indicadores de qualidade. Na semeadura foi avaliado o paralelismo entre as passadas do conjunto trator-semeadora em 120 pontos de cada sistema (direcionamento manual e automático). Foram avaliadas as perdas

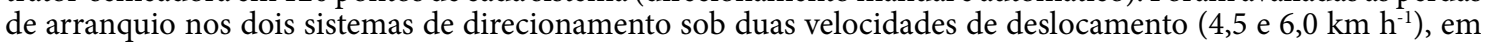
15 pontos de cada tratamento. Verificou-se que o paralelismo entre as passadas do conjunto trator-semeadora foi melhor quando se utilizou do piloto automático, além da maior qualidade da operação. A velocidade de deslocamento não influenciou as perdas de arranquio. Não houve diferenças nas perdas visíveis de arranquio, porém quando o arranquio foi realizado com o piloto automático obteve-se maior qualidade. Menores perdas invisíveis e totais de arranquio foram obtidas quando o arranquio foi realizado com o direcionamento automático, e qualidade superior foi obtida na velocidade de $4,5 \mathrm{~km} \mathrm{~h}^{-1}$; porém, a qualidade foi afetada negativamente sob operação manual. Portanto, o uso do piloto automático se mostrou eficaz na melhoria da precisão e da qualidade das operações.

Palavras-chave: Arachis hypogaea L., controle estatístico de processos, posicionamento relativo cinemático, paralelismo, perdas de arranquio 


\section{INTRODUCTION}

Different methods of Global Navigation Satellite System (GNSS) positioning include real-time kinematic relative positioning (RTK), which enables the quality of positions to be determined in the order of centimeters (Baio \& Moratelli 2011).

The use of this technology in peanut crop is important due the possibility of reducing parallelism errors at sowing and reducing losses in mechanized harvesting due to the correct alignment of cutting knives and crop lines during the digging process; such losses represent a major problem in peanut crop.

In studies performed in the United States using autopilot for peanut crop, Ortiz et al. (2013) and Vellidis et al. (2013) found that mechanical peanut digging is performed with high precision, minimizing deviations from the line and providing lower digging losses and consequently higher financial return.

Studies have demonstrated the economic returns of peanut crop using an automatic targeting system based on RTK correction under different working conditions, such as that performed by Vellidis et al. (2014), who evaluated these returns at different curvatures and in different soil preparation systems (Ortiz et al., 2013).

However, technology is less used in Brazilian crops compared with the USA, and there is a lack of knowledge among farmers about the benefits of automatic guidance on sowing and digging operations, which generates high losses.

Therefore, the aim of this study was to evaluate self-steering technology compared with manual steering in mechanized operations for peanut crop, in terms of the quality of these operations through statistical process control.

\section{Material ANd Methods}

The study was conducted in a commercial peanut field, with soil classified as Ultisol, abrupt-to-moderate, gently undulating and undulating topography (Oliveira et al., 1999), with a medium textural class. The experimental area belonged to a farm in the municipality of Dobrada in the State of São Paulo, Brazil (21 $21^{\circ} 16^{\prime \prime} \mathrm{S}$ and $48^{\circ} 24^{\prime} 33^{\prime \prime} \mathrm{W}, 565$ m altitude), with gently rolling topography, and Aw climate according to the Köppen-Geiger classification (Peel et al., 2007).

A tractor with automatic guidance was used for both sowing and digging, via hydraulic pilot with satellite navigation, whose real-time kinematic correction signal was sent via UHF radio issued by a fixed base, installed in a tower. A Topcon receiver, model System 150, was used at the base station. A Topcon, AGI-3 receiver, connected to a GX-45 monitor, was used by the tractor. Sowing was designed using Auto-CAD R14 software. This project was carried out from the sower working area, along the automatic guidance lines spaced at $3.60 \mathrm{~m}$ (each pass has four rows of sowing with $0.90 \mathrm{~m}$ spacing). Based on this, another project was designed to carry out digging with a working area of $1.80 \mathrm{~m}$ (two digging rows).

Manual operations were performed using sower marker lines, and for digging, the operator's vision was used to drive within crop rows.

At sowing, the soil had $15.8 \%$ water content based on the standard gravimetric method. The soil was prepared using the conventional method (one plowing and two disking). Peanut seeds of the cultivar Granoleico were used with $0.90 \mathrm{~m}$ spacing between rows, sowing density of 20 seeds $\mathrm{m}^{-1}$, and sowing depth of $0.06 \mathrm{~m}$. A Massey Ferguson, model 7150, tractor was used, with $4 \times 2$ front wheel-assisted drive (FWAD), a $110 \mathrm{~kW}(150 \mathrm{hp})$ engine at rated speed, gearbox operating on second low gear, engine speed of $2000 \mathrm{rpm}$, displacement speed of $6.3 \mathrm{~km} \mathrm{~h}^{-1}$, and pneumatic sower-fertilizer PHT3 Supreme brand, with double discs mismatched for seed deposition and groove opening for fertilizer deposition, and double press wheels in "V", operating in regulation of four sowing rows.

Peanut digging was performed 130 days after sowing (DAS) at $69 \%$ maturity, based on the methodology reported by Williams \& Drexler (1981), string bean productivity of $5150 \mathrm{~kg} \mathrm{ha}^{-1}$, following the methodology of Silva \& Mahl (2008), $11.0 \%$ soil water content (Buol et al. 2011), and a string bean water content of $29.3 \%$ (Brasil, 2009). The same tractor was used for sowing in the third low $\left(4.5 \mathrm{~km} \mathrm{~h}^{-1}\right)$ and third high $\left(6.0 \mathrm{~km} \mathrm{~h}^{-1}\right)$ gear, at an engine speed of $1500 \mathrm{rpm}$ (digging manufacturer's recommendation), and a digger-inverter, Santal brand, AIA2 model (harvesting two rows forming one windrow), working to $1.8 \mathrm{~m}$ width and $0.15 \mathrm{~m}$ depth. In this study, both implements (planter and inverter) were mounted on the three-point tractor coupling.

Digging treatments were arranged with and without the autopilot and two displacement speeds $\left(4.5\right.$ and $\left.6.0 \mathrm{~km} \mathrm{~h}^{-1}\right)$. Fifteen points were collected per treatment $(2 \times 2$ factorial $)$ spaced $50 \mathrm{~m}$ under a completely randomized design, for a total of 60 sampling points. The treatments were termed as follows: PS1 - autopilot at a displacement speed of $4.5 \mathrm{~km} \mathrm{~h}^{-1}$; PS2 autopilot at a displacement speed of $6.0 \mathrm{~km} \mathrm{~h}^{-1}$; MS1 - manual operation at a displacement speed of $4.5 \mathrm{~km} \mathrm{~h}^{-1}$; MS2 - manual operation at a displacement speed of $6.0 \mathrm{~km} \mathrm{~h}^{-1}$.

The experimental design of the sowing experiment was completely randomized, and the data were collected at equals spacings $(50 \mathrm{~m})$. At sowing, a total of 240 points were collected to evaluated the variable parallelism, in treatments with and without autopilot. Overall, 120 points using the autopilot and 120 manually operated points were collected, spaced $50 \mathrm{~m}$. Half of all points were collected in the direction of the tractorsower set displacement, and half were collected in the opposite direction to improve variability. Parallelism between passes of the tractor-sower set was evaluated by measuring the spacing between them with a centimeter ruler.

For mechanical digging, losses were evaluated using the classification proposed by Silva \& Mahl (2008) in term of visible losses (above ground), invisible losses (below ground), and total losses, corresponding to the sum of visible and invisible losses, which ware analyzed during the peanut digging operation.

To determine visible digging losses (VL) with digging, all string beans and peanut seeds found on the soil surface were collected after the digging operation. To collect this material, the windrow was carefully removed by placing a metal frame of $2 \mathrm{~m}^{2}$ on the site. After collection, the peanut string beans were placed in paper bags and the mass was determined on a digital scale with a resolution of $0.01 \mathrm{~g}$. Samples were then placed in an electric oven at $105 \pm 3{ }^{\circ} \mathrm{C}$ for $24 \mathrm{~h}$ (Brasil, 2009). 
After drying, the string bean mass was determined, and the value of digging losses was converted to $\mathrm{kg} \mathrm{ha}^{-1}$ after correction for $8 \%$ water content.

Invisible losses (IL) in digging were determined in the same location evaluated for (VL), with the collection of peanut string beans and seeds found below the soil surface. The soil was removed with the aid of a hoe, and the soil contents were sieved within the frame. Then, the string beans located at a depth of $0.15 \mathrm{~m}$ were manually collected, followed by the same procedure described for (VL). The working depth of the digger-inverter was $0.15 \mathrm{~m}$.

Total digging losses (TL) in digging were determined based on the sum of visible and invisible losses.

Data were analyzed by analysis of variance, applying the F test at $\mathrm{p} \leq 0.05$.

Regarding the quality of the operation, the results were analyzed using a statistical control process (SCP), which is a statistical tool used for quality control of the stages in the process. They were used to evaluate control charts on sequential variables and graphics to identify causes of instability not inherent in the process that are considered critical. These charts present central lines (overall mean and mean amplitude) as well as the upper and lower control limits (UCL and LCL, respectively), calculated based on the standard deviation of the variables (for UCL, the mean plus three-times the standard deviation; for LCL, the mean minus three-times the deviation when bigger than zero).

For the control analysis chart, the Automotive Industry Action Group (AIAG) test was used, which generates the corresponding errors for each variable. Although the test allows the generation of various kinds of errors, only "Type 1 " errors were considered in this study, which consider any point bigger than the UCL or smaller than the LCL outside of the limit control.

In addition to the statistical control limits, specific limits were used according to the desired quality, including specific upper control limit (SUCL); specific lower control limit (SLCL), and specific limit of variation (SLV), which are the first two displayed on the chart of individual values and the latter in the mobile amplitude chart. Such limits for each variable were as follows: parallelism between passes SLCL: $85 \mathrm{~cm}$; SUCL: $95 \mathrm{~cm}$, SLV: $10 \mathrm{~cm}$; visible losses on digging SLCL: null (desirable that there are no losses); SUCL: $150 \mathrm{~kg} \mathrm{ha}^{-1}$ (approximately 3\% productivity); SLV: $30 \mathrm{~kg} \mathrm{ha}^{-1}$; invisible losses on digging SUCL: $350 \mathrm{~kg} \mathrm{ha}^{-1}$ (approximately 7\% productivity); SLV: $40 \mathrm{~kg} \mathrm{ha}^{-1}$; and total losses on digging SUCL: $500 \mathrm{~kg} \mathrm{ha}^{-1}$ (approximately 10\% productivity); SLV: $50 \mathrm{~kg} \mathrm{ha}^{-1}$ (Bertonha, 2011).

\section{Results AND Discussion}

Differences in parallelism between the passes of the tractor-sower set were observed among treatments (Table 1) in the sowing operation; when using guidance via autopilot, the spacing between passes was closer to the adjusted, which was $0.90 \mathrm{~m}$.

When manual guidance was performed by the operator, there was a mean increase of $0.095 \mathrm{~m}$ in spacing compared with that observed with autopilot guidance; therefore, although
Table 1. Mean test for parallelism between passes of the tractorsower set in the sowing operation

\begin{tabular}{lc}
\hline Operations & Parallelism (cm) \\
\hline Manual & $100.1 \mathrm{~b}$ \\
Automatic pilot & $90.6 \mathrm{a}$ \\
Ftest & $125.1^{*}$ \\
\hline
\end{tabular}

* Significant by $\mathrm{F}$ test at $\mathrm{p} \leq 0.05$. Means followed the same letters do not differ by Tukey test at $\mathrm{p} \leq 0.05$

spacing is incorrect, there is a decrease in the seeded area when manually operated. Furthermore, at some points, the spacing was lower than desired, which may reflect competition between plants.

When the increase in row distance with manual steering was systematically applied in the parallelism, there was a loss of $2.6 \%$ sowm area for the working width used $(3.6 \mathrm{~m})$, which under the conditions studied, had a productivity of $5150 \mathrm{~kg} \mathrm{ha}^{-1}$, resulting in a $135.9 \mathrm{~kg} \mathrm{ha}^{-1}$ loss of productivity due to the under-utilization of the area during sowing.

With ideal spacing of $0.90 \mathrm{~m}$, and considering the useful area of the sower of $3.6 \mathrm{~m}$, there is an average error of $0.061 \mathrm{~m}$ when guided via autopilot and $0.1005 \mathrm{~m}$ when operated manually.

Regarding the quality of the two systems, the parallelism remained stable or under statistical control, when guided by autopilot (Figure 1A), indicating that variability can be attributed only to randomness of the sowing process, and is intrinsic to the process.

Manually operated sowing presented points in the chart of mobile amplitude, exceeding the upper control limit due to the high variability of the collected data. This demonstrates instability of the process due to special causes, which can be explained by the occurrence of one or more of the six factors (material, manpower, method, machine, measurement, and environment) (Samohyl \& Alves, 2005). In this case, operator guidance errors (manpower factor) and poorly adjusted marker lines of the sower (machine factor) may have caused this instability, leaving the process out of control, and thus affecting quality.

The quality of the autopilot system was further enhanced when observing acceptable values within the stipulated specific limits, where most of the points were within the specified control limits, with $87.50 \%$ Acceptable (Table 2) (SUCL and SLCL) and the total (100\%) was within the specified limit of variation (SLV). In addition, there were smaller coefficients of variation, standard deviation, and amplitude, less variability, and higher quality.

Manual operation, beyond the presented instability, obtained the most points above the specified upper control limit (SUCL), and great variability was shown by the distance between the upper and lower control limits of statistical control, and high amplitude, indicating low quality.

The results of this study can be explained by the findings of Vellidis et al. (2013), who reported that automatic guidance increases the alignment of the operation in peanuts, with error deviations below $2.5 \mathrm{~cm}$ obtained using the RTK system. In contrast, when operated without automatic guidance, it may be difficult for the operator to monitor the functioning of the mechanized set, and they may worry about displacing with minimal deviations, allowing larger displacing errors. 
A.
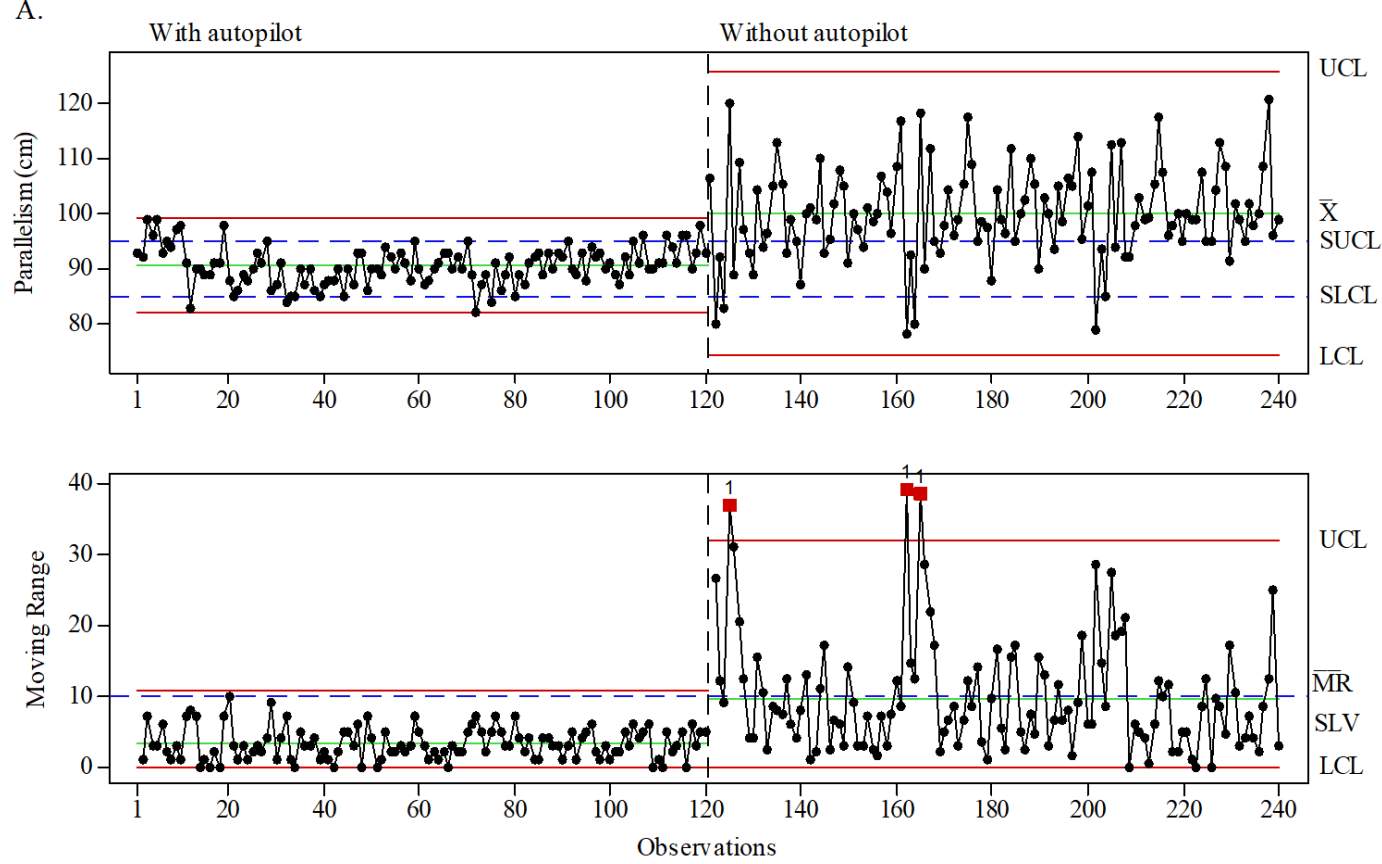

B.
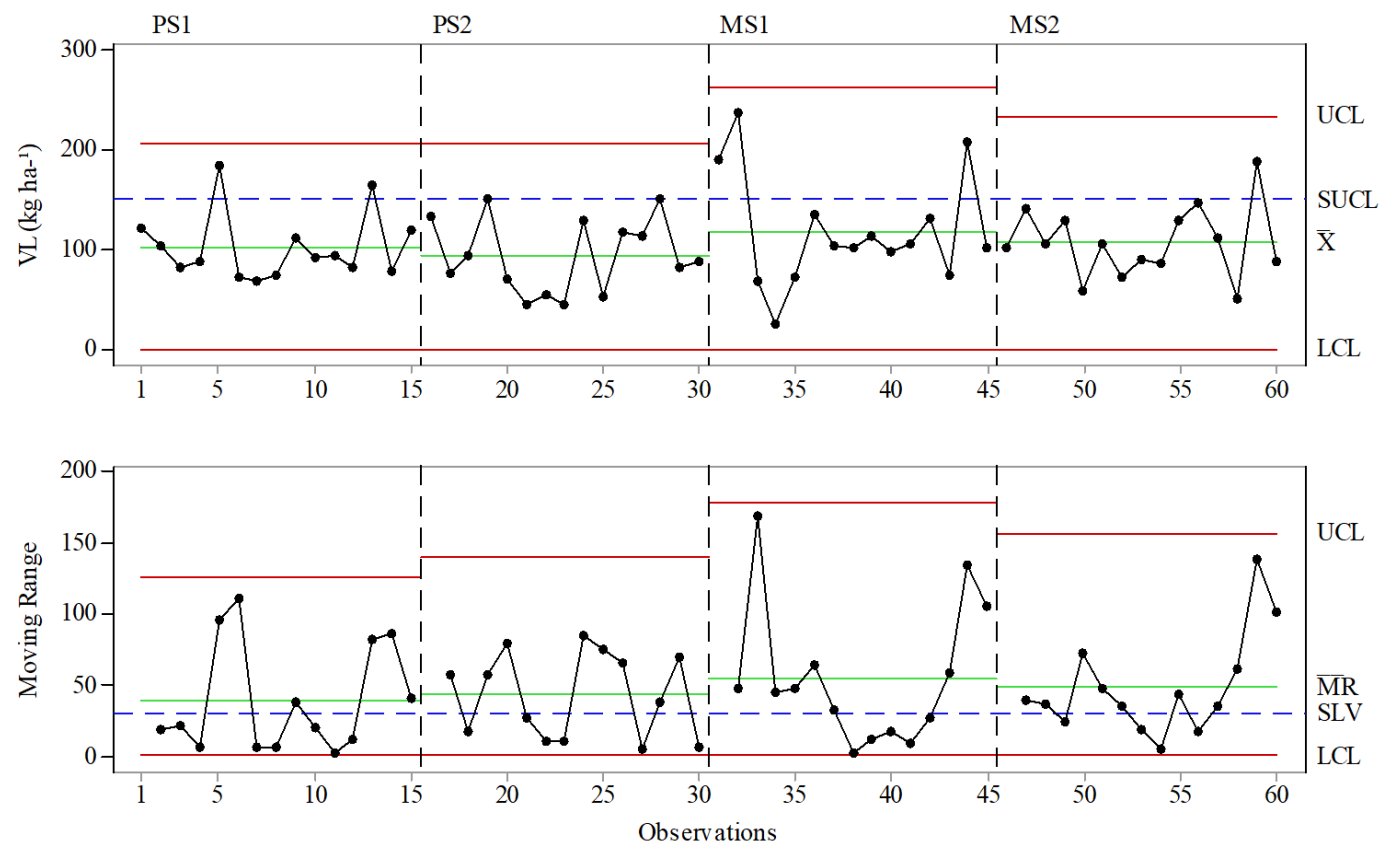

UCL - Upper control limit; LCL - Lower control limit; SUCL - Specific upper control limit; SLCL - Specific lower control limit; SLV - Specific limit of variation; X - Mean; MR - Moving range; PS1 - Autopilot at a displacement speed of $4.5 \mathrm{~km} \mathrm{~h}^{-1}$; PS2 - Autopilot at a displacement speed of $6.0 \mathrm{~km} \mathrm{~h}^{-1}$; MS1 - Manual operation at a displacement speed of $4.5 \mathrm{~km} \mathrm{~h}^{-1}$; MS2 - Manual operation at a displacement speed of $6.0 \mathrm{~km} \mathrm{~h}^{-1}$

Figure 1. (A) Parallelism control charts between passes of the tractor-sower set; (B) Control charts for visible losses on digging

In studies related to the implementation of crops, Santos et al. (2017) showed that using the precise point positioning method (PPP) for peanut sowing can result in a $3.7 \mathrm{~cm}$ tractorsower set parallelism error, which is bigger than the errors found in this experiment $(0.6 \mathrm{~cm})$ showing that RTK has greater accuracy than PPP.

Baio \& Moratelli (2011) reported that parallelism errors for mechanized sowing of sugarcane operations showed an accuracy of $3.30 \mathrm{~cm}$. Voltarelli et al. (2013) found error values up to $4.88 \mathrm{~cm}$ using autopilot for sugarcane planting with a working area of $3.0 \mathrm{~m}$ (two planting rows of $1.5 \mathrm{~m}$ each). Furthermore, Oliveira \& Molin (2011) found an average error in citrus seedling transplantation ( $7 \mathrm{~m}$ of spacing between rows) of $4 \mathrm{~cm}$ when performed by autopilot and $8 \mathrm{~cm}$ when performed manually. Silva et al. (2014) found an average parallelism error of $5 \mathrm{~cm}$ for citrus seedlings transplanted with autopilot (3.5 $\mathrm{m}$ of spacing between rows).

Few studies in the literature have reported the use of automatic guidance analysed with tools of statistical control, especially with representative specific control limits. Voltarelli et al. (2013) and Silva et al. (2014) used control charts to monitor the quality of automatic guidance; however, the application of specified limits allows acceptable intervals to be stipulated, increasing the accuracy of the pattern evaluation and the comparison between variables.

Regarding the quality of the operation, other researchers have used control charts to evaluate the quality of parallelism made by autopilot guidance, which were effective for detecting 
Table 2. Percentage of points within the limits specified for parallelism between the passes of the tractor-sower set and digging losses

\begin{tabular}{|c|c|c|c|c|c|c|c|c|}
\hline \multirow{2}{*}{ Operations } & \multicolumn{2}{|c|}{ Control (\%) } & \multirow{2}{*}{ Below } & \multicolumn{2}{|c|}{ Variation (\%) } & \multirow{2}{*}{$\begin{array}{c}\text { CV } \\
(\%)\end{array}$} & \multirow{2}{*}{$S$} & \multirow[t]{2}{*}{$\mathbf{R}$} \\
\hline & Acceptable & Above & & Acceptabe & Above & & & \\
\hline \multicolumn{9}{|c|}{ Passes of the tractor-sower set } \\
\hline Autopilot & 87.50 & 9.17 & 3.33 & 100 & 0 & 3.87 & 3.50 & 17.00 \\
\hline Manual Operation & 30 & 85 & 5.00 & 65.55 & 34.35 & 8.55 & 8.56 & 43.00 \\
\hline \multicolumn{9}{|c|}{ Visible losses on digging } \\
\hline PS1 & 86.66 & 13.34 & - & 57.14 & 42.86 & 32.85 & 33.56 & 115.75 \\
\hline PS2 & 100 & 0 & - & 42.86 & 57.14 & 39.32 & 36.77 & 105.55 \\
\hline MS1 & 85.71 & 14.29 & - & 35.71 & 64.29 & 47.67 & 56.10 & 212.00 \\
\hline MS2 & 93.33 & 6.67 & - & 28.57 & 71.43 & 33.79 & 36.09 & 137.50 \\
\hline \multicolumn{9}{|c|}{ Invisible losses on digging } \\
\hline PS1 & 100 & 0 & - & 71.43 & 28.57 & 39.41 & 48.00 & 151.30 \\
\hline PS2 & 100 & 0 & - & 42.86 & 57.14 & 62.33 & 48.80 & 182.60 \\
\hline MS1 & 100 & 0 & - & 35.71 & 64.29 & 63.39 & 86.60 & 296.30 \\
\hline MS2 & 100 & 0 & - & 50.00 & 50.00 & 43.23 & 56.60 & 187.50 \\
\hline \multicolumn{9}{|c|}{ Total losses on digging } \\
\hline PS1 & 100 & 0 & - & 50.00 & 50.00 & 27.65 & 62.50 & 200.50 \\
\hline PS2 & 100 & 0 & - & 35.71 & 64.29 & 38.26 & 65.20 & 225.20 \\
\hline MS1 & 100 & 0 & - & 50.00 & 50.00 & 48.09 & 122.30 & 407.80 \\
\hline MS2 & 100 & 0 & - & 57.14 & 42.86 & 21.25 & 50.50 & 174.40 \\
\hline
\end{tabular}

PS1 - Autopilot at displacement speed of $4.5 \mathrm{~km} \mathrm{~h}^{-1}$; PS2 - Autopilot at displacement speed of $6.0 \mathrm{~km} \mathrm{~h}^{-1}$; MS1 - Manual operation at displacement speed of $4.5 \mathrm{~km} \mathrm{~h}{ }^{-1}$; MS2 - Manual operation at displacement speed of $6.0 \mathrm{~km} \mathrm{~h}^{-1}$; CV - Coefficient of variation; S - Standard deviation, R - Range

critical points and factors affecting the efficiency of operations (Voltarelli et al., 2013; Silva et al., 2014).

When evaluating losses (Table 3 ), the displacement velocity of machines had no effect on peanut digging losses for both piloting methods. As the effective field capacity depends on the working width (which in this case was fixed) and on the displacement speed, the recommendation would be to operate at the highest speed $\left(6 \mathrm{~km} \mathrm{~h}^{-1}\right)$ in order to increase the worked area over time without changing the value of the losses.

The speed of the operation performed with autopilot or manually did not change the values of visible losses for peanut digging.

The autopilot operation, unlike for the visible losses, provided smaller invisible losses, and therefore total losses, with a reduction of 24.98 and $19.46 \%$, respectively. This indicates that the use of automatic guidance was effective for reducing invisible losses, and can operate with the highest speed because it does not affect the losses, thereby increasing the operating capacity. The use of the autopilot reduced the total losses in $47.89 \mathrm{~kg} \mathrm{ha}^{-1}$ of peanut pods.

Regarding the quality of the operation for visible losses, all treatments were stable under the statistical process control

Table 3. Mean values and F test for visible (VL), invisible (IL), and total (TL) losses on digging

\begin{tabular}{|c|c|c|c|}
\hline Treatments & $\overline{V L}$ & $\mathrm{IL}$ & $\mathrm{TL}$ \\
\hline Operations (0) & & $\left(\mathrm{kg} \mathrm{ha}^{-1}\right)$ & \\
\hline Autopilot & $97.82 \mathrm{a}$ & $100.38 \mathrm{~b}$ & $198.20 \mathrm{~b}$ \\
\hline Manual operation & $112.28 \mathrm{a}$ & $133.81 \mathrm{a}$ & $246.09 \mathrm{a}$ \\
\hline Speed $(V)$ & & $\left(\mathrm{kg} \mathrm{ha}^{-1}\right)$ & \\
\hline $4.5 \mathrm{~km} \mathrm{~h}^{-1}$ & $109.95 \mathrm{a}$ & $130.17 \mathrm{a}$ & $240.12 \mathrm{a}$ \\
\hline $6.0 \mathrm{~km} \mathrm{~h}^{-1}$ & $100.15 \mathrm{a}$ & $104.02 \mathrm{a}$ & $204.17 \mathrm{a}$ \\
\hline \multicolumn{4}{|l|}{ F test } \\
\hline 0 & $1.810^{\text {ns }}$ & $4.357^{\star}$ & $5.588^{\star}$ \\
\hline V & $0.833^{\text {ns }}$ & $2.668^{\text {ns }}$ & $3.153^{\text {ns }}$ \\
\hline $0 \times V$ & $0.012^{\text {ns }}$ & $1.665^{\text {ns }}$ & $0.928^{\text {ns }}$ \\
\hline LSD & 21.53 & 32.08 & 40.87 \\
\hline
\end{tabular}

${ }^{\mathrm{ns}}$ Not significant; ${ }^{*}$ Significant by $\mathrm{F}$ test at $\mathrm{p} \leq 0.05$; The same letters in the column differ not from each other by Tukey test at $\mathrm{p} \leq 0.05$
(Figure 1B), and the difference in quality between treatments was due to the distinct variations obtained.

Similar results for displacement speed were observed in the system; that is, quality is maintained within each guidance system as the speed changes. However, when using the autopilot, independent of speed, the quality was superior due to the shorter distance between the lower and the upper limits of statistical control, as observed on the individual value chart for mobile amplitude (Figure 1B). This higher quality is further enhanced when observing higher values within the acceptable limit of variation, with $86.66 \%$ acceptable for PS1 and 100\% acceptable for PS2 (Table 2), in addition to lower standard deviation and amplitude, and therefore, a lower variability of visible losses when the operation is performed on autopilot.

A similar result to visible losses was found for invisible losses in terms of quality (variability). When using the autopilot at two evaluated speeds, one point was out of control (Figure 2A) causing instability. The non-randomness can be justified based on points outside the control limits, which, according to Toledo et al. (2008), are considered atypical or outliers, which are uncommon points that appear far from other observations, which may be above or below the average, and may be regarded as values that do not represent the true behavior of the data set, since they occur only once.

Despite the instability displayed, all points were within the SUCL; therefore, all treatments maintained a standard of quality. For smaller distances between statistical controls limits (UCL and LCL) when using the autopilot (Figure 2A), the invisible losses also indicated better quality, similar to visible losses.

Among the velocities measured with the autopilot, the lower speed $\left(4.5 \mathrm{~km} \mathrm{~h}^{-1}\right)$ generated most data within the acceptable limit and with a smaller coefficient of variation, standard deviation, and range (39.41\%, 48.00 and $151.30 \mathrm{~kg} \mathrm{ha}^{-1}$, respectively) (Table 2), and therefore, less variability and better quality despite no differences between variables for both displacement speeds (Table 3). 
A.
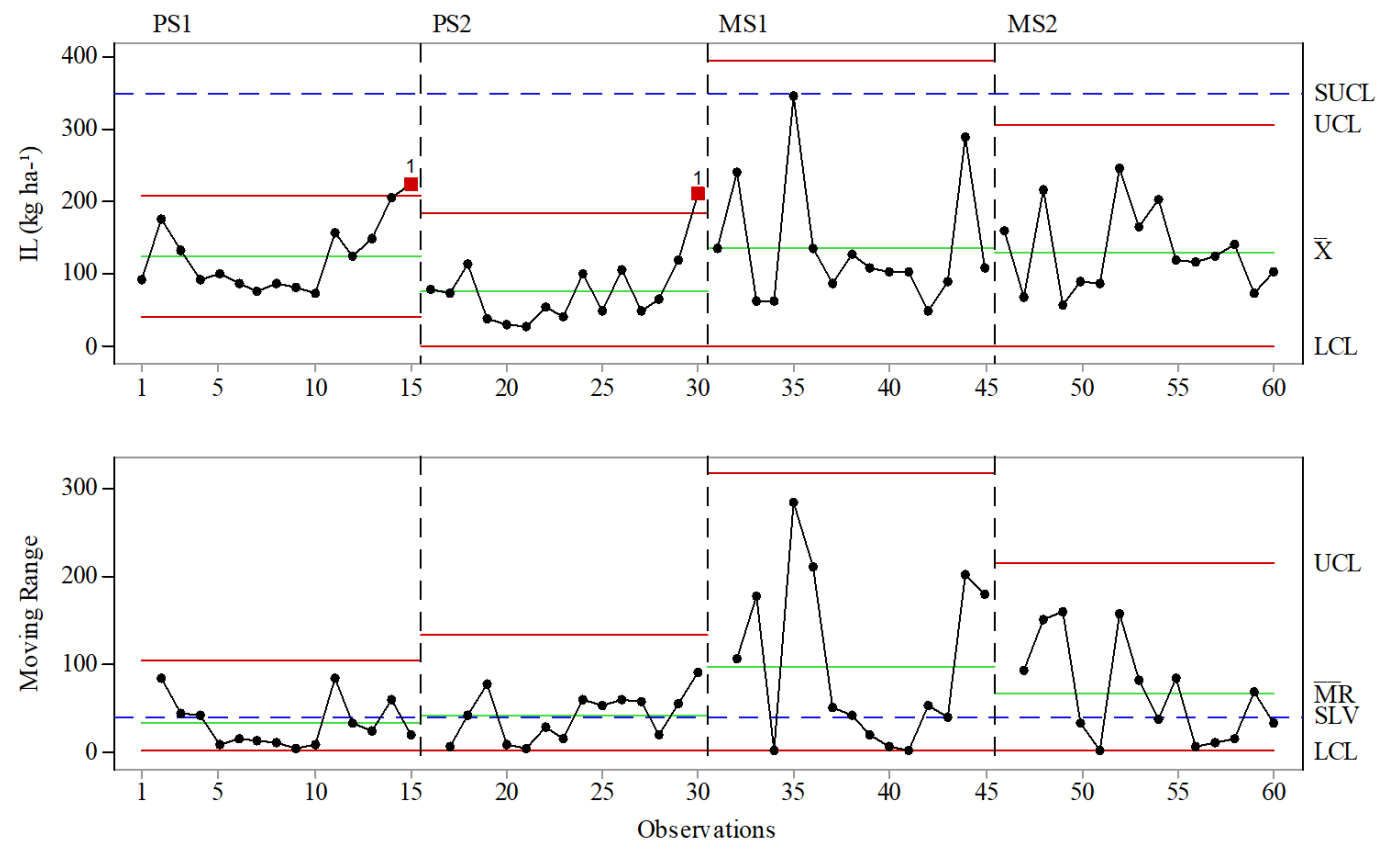

B.
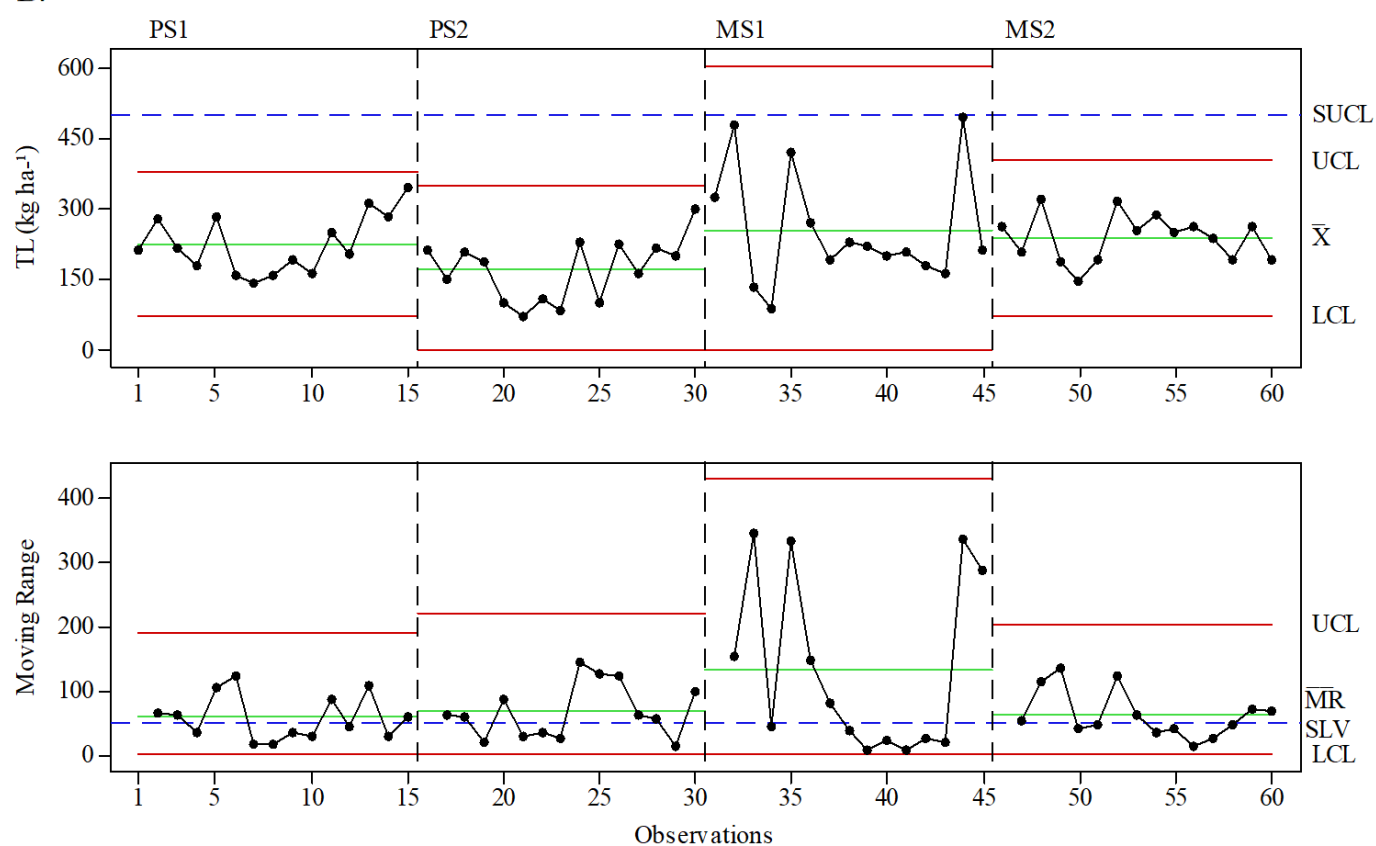

PS1 - Autopilot at displacement speed of $4.5 \mathrm{~km} \mathrm{~h}^{-1}$; PS2 - Autopilot at displacement speed of $6.0 \mathrm{~km} \mathrm{~h}^{-1}$; MS1 - Manual operation at displacement speed of $4.5 \mathrm{~km} \mathrm{~h}{ }^{-1}$; MS2 - Manual operation at displacement speed of $6.0 \mathrm{~km} \mathrm{~h}^{-1}$; UCL - Upper control limit; LCL - Lower control limit; SUCL - Specific upper control limit; SVL - Specific variation limit; X - Mean; MR - Moving range

Figure 2. ( A) Control charts for invisible losses on digging; (B) control charts for total losses on digging

Because the total losses are the sum of the visible and invisible losses, quality was maintained by the pattern of variability. Notably, the process was kept under control (Figure 2B), indicating that the variability is attributable only to randomness of the digging process, i.e., it is intrinsic to the process. From the perspective of quality control, this demonstrates that both the operation system and the speed used were able to maintain an adequate standard of quality, which differs according to the variability of each treatment.

All points were within the specified limits of losses (Table 2); however, when operated manually at a speed of $4.5 \mathrm{~km} \mathrm{~h}^{-1}$, the statistical control limits were further away, following the same behavior observed for the visible and invisible losses, due to the high standard deviation (48.09\%) and amplitude
(407.80 $\left.\mathrm{kg} \mathrm{ha}^{-1}\right)$, causing greater variability, and therefore lower quality among the treatments.

The other three treatments (PS1, PS2 and MS2) maintained similar quality standards, with the distances between the statistical control limits near those observed in Figure 2B, even MS2 presented high losses (Table 3). All indices of quality indicators calculated were close.

In this study, the operation with autopilot provided smaller invisible and total losses. This indicates that the use of the autopilot was effective at aligning the digger-inverter with the lines of crop, directing the cutting knives in the correct position when the assembly was guided manually by the operator, since they act directly on the ground, promote the cutting of peanut tap roots, and dig them from the soil. Thus, 
automatic guidance provides better alignment and inverts the plants by cutting the main root, leaving lower amounts of string beans on the soil due to the parallel cut with the crop rows, reducing the invisible losses and consequently, total losses. This corroborates the findings of Santos et al. (2018) who worked with real time extended GNSS and decreased the total losses in peanut digging.

Ortiz et al. (2013), working on conventionally prepared soil, confirmed the accurate use of autopilot for peanut digging, which was performed in the middle of rows, minimizing deviations on lines and consequently providing lower loss and higher financial return. Furthermore, $18 \mathrm{~cm}$ deviation in the digging line when operated manually provided losses of up to $49 \%$ in string bean productivity compared with autopilot use. Ortiz et al. (2013) emphasized that the use of autopilot with RTK correction under dry conditions, as in the present study (11\% soil moisture content at the time of digging) was even more efficient at avoiding losses.

Similarly, Vellidis et al. (2013) studied mechanized peanut digging in sandy soil and reported lower losses using the autopilot operation, confirming the results obtained in the present study. Both under low-curvature conditions, and medium and high curvature conditions, automatic guidance favored smaller losses. Vellidis et al. (2013) also claimed that because peanuts have a solid canopy and are totally green at harvest, operation without autopilot makes it difficult to align the tractor with the longitudinal axis of the culture, while automatic guidance deviates from the center line by less than $2.5 \mathrm{~cm}$, which favors reduced losses. They concluded that the use of the pilot based on RTK correction to sow and dig peanuts resulted in substantial productivity gains and associated economic returns.

The mean total losses of the treatments used in the present study ranged from 3.3 to $4.9 \%$ productivity with an amplitude ranging from 1.4 to $9.6 \%$ productivity. These values are considered low compared to those reported in previous studies in North America, in which the digging losses varied from 15 to $30 \%$ of the potential peanut yield (Ortiz et al. 2013).

Based on knowledge of the reduced total losses from digging with autopilot, and the mean error reduction of parallelism for sowing, it is possible to analyze the economic benefits of auto-steering. Based on the Brazilian market price of R $\$ 38.10$ per $25 \mathrm{~kg}$ bag of peanuts with bark, an increase in the gross economic return of $\mathrm{R} \$ 72.98 \mathrm{ha}^{-1}$ is generated with the use of autopilot in the digger, which clearly demonstrates an economic advantage in adopting this operation for peanut crop. Analyzing the mean error in parallelism using manual targeting, it is noted that underutilization of the sown area by $2.6 \%$ results in the producer loosing potential earnings of approximately $\mathrm{R} \$ 207.11 \mathrm{ha}^{-1}$. This is markedly reduced with the use of self-targeting, generating a financial return with the increased yield as a result of the better allocation of the tractor- sowing set pass in the production area.

In summary, the results obtained in the present study, which demonstrated improved results and quality of the indicators evaluated, corroborate the findings of previous national and international studies and suggest that use of autopilot for both the sowing and mechanized harvesting of peanuts is important for the correct implementation of the crop, leading to lower crop losses and enhanced quality of mechanized operations.

\section{Conclusions}

1. Parallelism between passes of the tractor-sower set was more accurate, and close to the adjusted when using the autopilot, coupled with improved quality of the operation and lower invisible and total losses on peanut digging.

2. The higher speed of $6.0 \mathrm{~km} \mathrm{~h}^{-1}$ should be used for digging because it did not affect losses.

\section{Literature Cited}

Baio, F. H. R.; Moratelli, R. F. Avaliação da acurácia no direcionamento com piloto automático e contraste da capacidade de campo operacional no plantio mecanizado da cana-de-açúcar. Engenharia Agrícola, v.31, p.367-375, 2011. https://doi.org/10.1590/S010069162011000200017

Bertonha, R. S. Variabilidade de perdas no arranquio mecanizado de amendoim: Estudo de caso. Jaboticabal: Universidade Estadual Paulista, 2011. 75p. Dissertação Mestrado

Brasil. Regras para análise de sementes. Brasília: Ministério da Agricultura, Pecuária e Abastecimento, 2009. 395p.

Buol, S. W.; Southard, R. J.; Graham, R. C.; McDaniel, P. A. Soil genesis and classification. 6.ed. Hoboken: Wiley-Blackwell, 2011. 556p. https://doi.org/10.1002/9780470960622

Oliveira, J. B. de; Camargo, M. N.; Rossi, M.; Calderano Filho, B. Mapa pedológico do Estado de São Paulo: Legenda expandida. Rio de Janeiro: Embrapa Solos, 1999. 64p.

Oliveira, T. C. A; Molin, J. P. Uso de piloto automático na implantação de pomares de citros. Engenharia Agrícola, v.31, p.334-342, 2011. https://doi.org/10.1590/S0100-69162011000200013

Ortiz, B. V.; Balkcom, K. B.; Duzy, L.; Santen, E. van; Hartzog, D. L. Evaluation of agronomic and economic benefits of using RTK-GPS-based auto-steer guidance systems for peanut digging operations. Precision Agriculture, v.14, p.357-375, 2013. https:// doi.org/10.1007/s11119-012-9297-y

Peel, M. C.; Finlayson, B. L.; McMahon, T. A. Updated world map of the Köppen-Geiger climate classification. Hydrology and Earth System Sciences Discussions, v.11, p.1633-1644, 2007. https://doi. org/10.5194/hess-11-1633-2007

Samohyl, R. W.; Alves, C. C. O monitoramento de processos industriais via gráficos de controle CUSUM. Revista Univille, v.10, p.72-80, 2005.

Santos, A. F. dos; Silva, R. P. da; Tavares, T. O.; Ormond, A. T. S.; Rosalen, D. L.; Assis, L. C. de. Parallelism error in peanut sowing operation with auto-steer guidance. Revista Brasileira de Engenharia Agrícola e Ambiental, v.21, p.731-736, 2017.

Santos, A. F. dos; Silva, R. P. da; Zerbato, C.; Menezes, P. C. de; Kazama, E. H.; Paixão, C. S. S.; Voltarelli, M. A. Use of real-time extend GNSS for planting and inverting penuts. Precision Agriculture, v.19, p.1-17, 2018. https://doi.org/10.1590/1807-1929/agriambi. v21n10p731-736

Silva, R. P. da; Mahl, D. Relatório do projeto de pesquisa: Perdas na colheita mecanizada do amendoim safra 2007/2008. Jaboticabal: Laboratório de Máquinas e Mecanização Agrícola, 2008. 47p. 
Silva, R. P. da; Voltarelli, M. A.; Cassia, M. T.; Vidal, D. O.; Cavichioli, F. A. Qualidade das operações de preparo reduzido do solo e transplantio mecanizado de mudas de café. Coffee Science, v.9. p.51-60, 2014.

Toledo, A. de; Tabile, R. A.; Silva, R. P. da; Furlani, C. E. A.; Magalhães, S. C.; Costa, B. O. Caracterização das perdas e distribuição de cobertura vegetal em colheita mecanizada de soja. Engenharia Agrícola, v.28, p.710-719, 2008. https://doi.org/10.1590/S0100-69162008000400011

Vellidis, G.; Ortiz, B.; Beasley, J.; Hill, R.; Henry, H.; Brannen, H. Using RTK-based GPS guidance for planting and inverting peanuts. In: Stafford, J. V. (ed.). Precision agriculture'13. Wageningen: Wageningen Academic Publishers, 2013. p.357-364.
Vellidis, G.; Ortiz, B.; Beasley, J.; Hill, R.; Henry, H.; Brannen, H. Reducing digging losses by using automated steering to plant and invert peanuts. Agronomy, v.4, p.337-348, 2014.

Voltarelli, M. A.; Silva, R. P. da; Rosalen, D. L.; Zerbato, C.; Cassia, M. T. Quality of performance of the operation of sugarcane mechanized planting in day and night shifts. Australian Journal of Crop Science, v.7, p.1396-1406, 2013. https://doi.org/10.3390/ agronomy 4030337

Williams, E. J.; Drexler, J. S. A non-destructive method for determining peanut pod maturity. Peanut Science, v.8, p.134-141, 1981. https:// doi.org/10.3146/i0095-3679-8-2-15 